Article

\title{
What Have We Learned about the Effects of the COVID-19 Pandemic on Consumer Behavior?
}

\author{
Fazel Hesham, Harizi Riadh *(D) and Nasr Khouadja Sihem
}

Citation: Hesham, F.; Riadh, H.; Sihem, N.K. What Have We Learned about the Effects of the COVID-19 Pandemic on Consumer Behavior? Sustainability 2021, 13, 4304. https:// doi.org/10.3390/su13084304

Academic Editor: José M. Gil

Received: 3 February 2021

Accepted: 7 April 2021

Published: 13 April 2021

Publisher's Note: MDPI stays neutral with regard to jurisdictional claims in published maps and institutional affiliations.

Copyright: (C) 2021 by the authors. Licensee MDPI, Basel, Switzerland. This article is an open access article distributed under the terms and conditions of the Creative Commons Attribution (CC BY) license (https:/ / creativecommons.org/licenses/by/ $4.0 /)$.
Department of Business Administration, College of Business, University of Bisha, 255, Al Nakhil, Bisha 67714, Saudi Arabia; hfazel@ub.edu.sa (F.H.); skhouaja@ub.edu.sa (N.K.S.)

* Correspondence: rharizi@ub.edu.sa; Tel.: +966-50-271-2693

\begin{abstract}
Background: This study aims to examine how behavioral variables interact with and stimulate purchasing decisions and influence the process of purchasing healthy foods during the COVID-19 pandemic. Method: Principal component analysis was carried out on a sample of 100 consumers of healthy foods in Saudi Arabia, and this made it possible to adapt the items to the context of the study. Exploratory and confirmatory analysis with 360 people was carried out. Confirmatory factor analysis provided reliable and valid scales, and multivariate analysis using structural equations and binary logistic regressions made it possible to validate the hypotheses. Results: The intention to buy increased among consumers of healthy foods. Women were more anxious about the COVID-19 pandemic than men, and they took considerable precautions to avoid contamination. The fear of COVID-19 was also more intense among the elderly population than younger people. The respondents indicated reduced visits to shops, restaurants, and markets. Gender and age moderated the relationship between the fear of COVID-19 and purchasing intention. Consumption risk also negatively affected purchasing intention. However, buying experiences and intention to buy led to increased purchases of healthy foods compared to other goods.
\end{abstract}

Keywords: consumer choice; behavioral change; COVID-19; health pandemic; healthy foods; purchase decision-making

\section{Introduction}

Since December 2019, the international community has been dealing with COVID-19, which spread to countries around the world and led to 41,104,946 confirmed cases and 1,128,325 confirmed deaths [1]. On 31 December 2020, Saudi Arabia was the most affected country in the Arab world and was 35th in the world, with 362,601 cumulative cases and 6214 cumulative deaths [2], despite previously experiencing a similar coronavirus epidemic, Middle East respiratory syndrome (MERS). This global crisis has had consequences at all economic and social levels. It has ravaged the world's economies and healthcare systems and instilled considerable fear, panic, and uncertainty in people of all countries [3,4]. With the spread of the pandemic, the mobility of people and goods was reduced in most countries as authorities were forced to apply a full or partial lockdown, leading to disruptions in the normal functioning of markets and economic and social facilities.

As described in [5], the COVID-19 pandemic has encouraged countries to diversify their trade to avoid external shocks. Indeed, the volatility in oil prices that we saw at the start of the COVID-19 crisis negatively impacted the oil-based economies of several countries around the world. In addition to drops in their gross domestic product (GDP), several countries, like Azerbaijan, have faced downturns in their oil and gas sectors, which consequently caused further downturns in the wider economy. In addition, in Azerbaijan, oil price developments have led to higher inflation and decreased consumption of goods and services [6,7].

Several questions have arisen that need to be answered based on an analysis of purchasing behaviors during the first wave of the COVID-19 pandemic. The relationship 
between government measures to combat the pandemic and their side effects, such as triggering panic buying, was examined in [8]. Consumers' sentiments influence their choice of purchases and shopping channels, and these have evolved along with the changes brought by COVID-19 and the related interventions of public authorities. The crisis has created two types of consumer: (i) consumers who remain pessimistic and continue to stockpile essential items, possibly preferring online shopping, and (ii) consumers who are relatively optimistic and continue to purchase nonessential goods and services through various channels. In a recent study examining the notions of self-regulatory theory and personal well-being, a relationship was established between COVID-19 as a disruptive perceived threat and stockpiling behavior [9].

Consumers are primarily affected by this pandemic because they represent the ultimate recipients of the various production, marketing, and other efforts of organizations [10]. This pandemic has had direct and indirect effects on lifestyles, purchasing power, desires, and the general consumption of goods and services [11-13]. In this sense, the devastating effects this has had on societies and economies of all sorts was reported in [14]. The importance of young employees feeling secure and satisfied with their jobs during the COVID-19 pandemic has been raised [15], along with the effect this has had on performance in organizations [16,17].

The world has experienced several health crises, such as the epidemics/pandemics caused by Ebola, severe acute respiratory syndrome (SARS), MERS, swine flu, and dengue [12], and mitigating actions have been employed to manage the health risks [18]. These health crises impacted consumer behavior in terms of purchasing behavior to mitigate health risk. In response to the effects of the COVID-19 pandemic, some researchers have speculated that human behavior will be pushed in different directions. For example, as shown in [13], the new normal for consumer behavior could be explored through several dimensions, such as understanding it through economies of consumption, savings, and health, realigning the current younger generation to new life principles and building a new segment of consumers, and inventing new products or services to attract the conscious generation. In several countries, this health pandemic has led to the limited availability of some goods, with commodity prices reacting strongly and reflecting changes in supply and demand caused by measures aimed at limiting contagion $[19,20]$. Managerial theory shows the destabilization of consumption during crises, particularly health crises, and previous research has also shown that consumer behavior is disrupted.

Several categories of people are more exposed to COVID-19 contamination, such as healthcare workers, who are among the most at-risk groups, especially those who care for COVID-19 patients [21].

Thus, from a physical and psychological viewpoint, food has never been so important in the daily lives of individuals, yet the COVID-19 pandemic seems to be changing humanity's relationship with food. Several nutritionists have emphasized the effects of healthy food choices, especially during a pandemic [22]. Healthy eating behaviors involve eating a variety of foods that provide the nutrients people need to stay healthy, feel good, and have plenty of energy. These nutrients include protein, carbohydrates, fats, water, vitamins, and minerals, and they are very important for human health. When combined with physical activity and maintaining a healthy weight, consuming healthy food is a great way to help the human body stay strong and healthy.

From a consumer behavior viewpoint, the literature classifies the numerous facets of purchasing decisions into internal and external variables, and they consider the consumption of goods during a pandemic to be a risky phenomenon [23]. However, to better identify consumer behavior and suggest actions to be taken, some authors insist that these risks must be examined in detail. For example, in [24,25], overall risk is divided into performance risk, social risk, physical risk, financial risk, psychological risk, and time-loss risk. For example, the physical risk of making purchases during a pandemic modifies consumers' purchasing behaviors and habits [2,26-29], and increased financial risk reflects the possibility of losing income following a purchase [30]. Consumption behavior during a 
pandemic is, therefore, sensitive to consumer attitudes $[31,32]$ and affected by the social distancing measures imposed by public authorities [11,31,33].

Unlike traditional marketing, in experiential marketing, salespeople can facilitate the creation of a special relationship between a brand and potential customers. This makes it possible to involve the buyer and generate feelings of well-being, which, in turn, builds a feeling of customer loyalty toward the brand. Over time, this technique guides the customer's shopping experience [34,35], such as when the customer is considered to act not just rationally but also emotionally based on accumulated experiences. However, recent research has shown that people's reactions to the COVID-19 pandemic vary according to age and gender [31,36]. People have different levels of concern about the effects of the pandemic, and this guides their behavior. For example, from an economic viewpoint, older people feel less affected than younger, working-age people, but from a physiological viewpoint, the health consequences have forced them to change their purchasing habits. Women also tend to be more concerned about the health effects of the pandemic than men. During the COVID-19 pandemic, personal factors such as age and gender are key factors explaining behavior, and they moderate the relationship between the intent to buy and purchasing decisions [31,37]. We therefore believe it is necessary to study consumer behavior during the COVID-19 pandemic and learn about the new characteristics of this behavior, so we can uncover the circumstantial specifics related to the purchasing process. This study, therefore, aims to understand some of the determinants and moderators of purchasing decisions by consumers of healthy foods.

The rest of this paper is structured as follows. First, we examine the theoretical background that characterizes the pandemic-related literature to explain consumer behavior. Next, we introduce our research model and propose related hypotheses, and then explain our empirical study and its data-collection methods and results. Next, we discuss these results by detailing all of the key findings and the theoretical and practical implications of this work, as well as its limitations and some suggestions for further research. Finally, we conclude the paper.

\section{Theoretical Background}

Several models have been used in the pandemic-related literature to explain consumer behavior. We review this literature to identify the main factors at play during a health pandemic.

\subsection{Risks to Consumption during a Health Crisis}

Among the consequences of the COVID-19 pandemic, we have seen the closing of shops and other businesses for months. Consumers have avoided public places, stores, and cultural events, even when such establishments were open. As a result, consumers began to change their purchasing behaviors and habits in a sustainable way [26-29,32].

In pandemic times, risk attitude and risk perception are the most important factors driving consumer behavior. Risk attitude reflects a consumer's interpretation of the actual risk, and constitutes a subjective interpretation of possibly being exposed to risk [13]. For example, during the pandemic, consumers sought to reduce risk by limiting their visits to shops and restricting their purchases to essential items, redirecting much of their expenditure to online commerce instead. In addition, with green marketing, consumers are willing to pay more for something if doing so helps to create a cleaner and greener environment. Several authors have shown a significant relationship between the consumption of healthy foods and consumers' purchasing intentions [38,39]. However, this relationship was found under normal conditions, and there is no indication that it persists during a pandemic. Indeed, there may be a continued risk of contamination from goods or packaging despite precautions taken at the point of sale [40].

In their consumption activities, consumers perceive direct and indirect risks [41]. However, in the extant literature, risks are treated either as a global construct or as a 
multidimensional variable, where each dimension is a function of the situation and the type of object being considered [42].

\subsection{Consumers' Shopping Experiences}

Experience is an element of experiential marketing, with the economic and social context explaining its adoption as a marketing tool. In economics, technology, competition, and wealth are key factors that drive an experience economy [43]. In sociology, researchers posit that people are living in increasingly more artificial environments, and are disenchanted by a plethora of choices, increased stress, continually increasing imperatives, and a lack of free time. In this context, considering the emotional aspect, consumers seek to fulfill a desire for distraction, discovery, sensation, and "hedonistic gratification" through their shopping experiences. To cover up the inconvenience of the modern way of life, and to differentiate itself from increasingly fierce competition, the artificial environment must be attractive in terms of its aesthetics and the image it reflects [44]. Based on this perspective, "total design stores" have appeared, and mass-market stores create sensory stimuli that give shoppers a special feeling that modifies their emotional and conative state and, consequently, their purchasing behaviors. Thus, sociologists note an evolution into postmodern consumers with new expectations. These consumers seek to immerse themselves in experiences rather than make simple purchases.

Finally, although they are rational, these postmodern consumers are looking for hedonism, aestheticism, escape, social connection, original and extraordinary experiences, and spiritual experiences [45]. We may consider the shopping experience as being the result of a co-creation or a response, or it may be a subjective reaction to an interaction comprising feelings and knowledge [46]. Indeed, feelings and knowledge are formed when sets of stimuli or cues are perceived through different contact points. Each consumer can engage in an experience on the sensory (through the perception of sensory stimuli in the atmosphere), emotional (or affective), intellectual (or cognitive), relational (or social), behavioral (or physical), and spiritual levels. In addition, the shopping experience can take place before, during, and after the transaction, making it memorable, with either a positive or negative evaluation.

\subsection{Purchasing Intentions during a Health Crisis}

Previous research has shown a direct link between the intention to buy and consumer buying behavior. Indeed, the intention to buy has been generally regarded as a process linked to buying behavior, and it relates to consumers' attitudes and opinions about specific products and the extent to which they intend to buy the products in the future. This concept has evolved in the literature since the work of [47], which considered individual behavior to be a state of moral eagerness, exerting a dynamic influence that guides an individual's response. Further, consumers' intention to buy is considered in [48] as a collection of individual acts directly related to the purchase and use of goods and services. These individual actions encompass the preceding decision-making process that determines their actions. Purchasing intention has also evolved into a set of instructions that individuals give to themselves, so they act in very specific ways [49,50], or, alternatively, it could be considered to be the degree of a consumer's conviction to buy (or repurchase) a particular product or service or do business with a specific organization. Finally, purchasing intention could reflect a situation where a consumer tends to buy specific products under certain conditions [33].

The restrictive measures taken by countries to limit the spread of the virus have disrupted supply chains and increased the prices of raw materials $[19,20]$. The desire to obtain a daily diet often overrides health concerns and the fear of catching COVID-19, leading to noncompliance with lockdown measures and crowded stores and markets. Thus, from a physical and psychological viewpoint, while food has always been present in people's daily lives, the COVID-19 health pandemic seems to have changed their relationship with food. 


\subsection{Sociodemographic Variables}

Extant research posits that the effects of the COVID-19 pandemic on a consumer's attitude depend on the individual's gender, age, and income. Indeed, people in different age groups have reacted differently to this health pandemic in general, as shown in [31] by a survey of American and British consumers, in which $96 \%$ of those considered to be millennials and generation $\mathrm{Z}$ were found to be concerned about the pandemic and its economic effects. This led these younger consumers to modify their behaviors more dramatically than older generations, who have been slightly less affected and shown fewer changes in their purchasing habits. That study also found that men shopped online and avoided in-store experiences more than women. Consequently, during the COVID-19 pandemic, variations in behavior have depended on gender, with women being more likely to be concerned about the effects [37].

\subsection{Moderating Variables for Consumer Behavior}

Certain variables play a role in moderating the relationships between the factors of consumer behavior, such as the fear of catching COVID-19. In theory, a moderating variable is one that influences the direction and/or strength of a relationship between an independent variable and a dependent variable [51]. Moderate regression analysis is an approach that maintains the integrity of a sample and acts as a means of controlling for the effects of moderating variables. Several interactions between the variables are used in an attempt to control the relationship between the endogenous variable and the moderating exogenous variables. As explained in [51], a moderating effect exists if we can prove a significant interaction between the explanatory variable (purchasing intention) and the potential moderator (gender, age) and the variable being explained (making a purchase). These moderating relationships are investigated in the quantitative section of this study to better explain the ways in which the variables interact.

\section{Research Model and Hypotheses}

\subsection{Impacts of Exposure to Several Risks}

Several successive works [24,52-54] have distinguished risks according to their properties. In $[24,25]$, all types of risk that are involved in acts of consumption are summarized and detailed. For example, in the process of consumption, a consumer may perceive the quality of the product as not being in accordance with his or her expectations (performance risk). In addition, a purchased item may be perceived to degrade the individual's image in the eyes of his or her social contacts (social risk). Particularly during a health crisis, certain goods may be considered dangerous to the health of consumers and their families (physical risk), so they may spend more on healthy foods. In this situation, the health risk can overcome the financial risk, which reflects the chance of monetary loss associated with a purchase. In order to satisfy their needs, consumers may buy healthier foods at higher prices than is typical [55], even if they may be available elsewhere at a lower cost [30]. Finally, consumption can lead to disappointment with oneself (psychological risk).

Furthermore, psychological risk involves a loss of self-esteem or an increase in anxiety due to purchasing a product. Among consumers, this uncertainty is caused by a lack of awareness of their own needs, a certain inability to prioritize their choices, and a lack of confidence in their judgment, coupled with an inability to distinguish the most predictive attributes of the objects being evaluated [24]. In summary, during a pandemic, consumers' perceptions of risk can influence their buying intention when shopping for healthy foods. Hence, we posit the following hypothesis:

Hypothesis 1 (H1). Exposure to risk while shopping for healthy foods during the COVID-19 pandemic negatively influences the intention to buy. 


\subsection{Impacts of Shopping Experiences on Consumers' Intention to Buy}

Several researchers have found an increase or decrease in shopping during the COVID19 pandemic, and most sales of products and services have moved online in response to consumer demands and the need to mitigate the negative effects of lockdown restrictions imposed by governments. Hence, we posit the following hypothesis:

Hypothesis 2 (H2). The shopping experience positively influences the intention to buy healthy foods during the COVID-19 pandemic.

\subsection{Impacts of Shopping Experiences on Consumers' Intention to Buy}

The increased consumption of healthy products with a dietetic orientation since the start of the COVID-19 pandemic is highlighted in [32]. According to this author, consumers report that they think organic and healthy products are more natural than other food products, so consumers who are afraid of developing chronic diseases like obesity and diabetes prefer them. In the Saudi context, which is characterized by the excessive consumption of sweet and fatty foods [55-59], it is imperative to examine the intention to buy healthy foods during the COVID-19 pandemic. Hence, we posit the following hypothesis:

Hypothesis 3 (H3). The intention to buy positively influences consumers' purchasing of healthy foods during the COVID-19 pandemic.

\subsection{Impacts of Consumers' Gender and Age on the Relationship between Purchase Intention and Purchase Decision}

Sociodemographic variables such as age and gender moderate consumers' purchasing behavior during the COVID-19 pandemic. Unfortunately, for numerous reasons related to the context of this study, we could not include income as a moderating variable. In the preliminary phase of the study, we observed that the Saudi respondents declined to declare their income, making it difficult for them to continue participating. We therefore postulate our fourth hypothesis:

Hypothesis 4 (H4). During the COVID-19 pandemic, the consumer's age and gender moderate the relationship between purchasing intention and purchasing decision.

\subsection{Impacts of the Moderating Variables on Other Relationships}

As we will explain in this study, during our preliminary exploratory study, we found that purchasing decisions were influenced by other situational factors, such as ease of purchase. An easy purchase will increase a consumer's preference for a certain item. This may be because it is presented clearly and visibly and is easier to locate [60]. The respondents stated that increased variety within an assortment, as they perceived it, is a motivating factor, and may influence their choice of goods in a supermarket, especially during the current health crisis, when they are motivated to spend less time in stores. This finding confirms the contributions of several studies showing an empirical threshold of variety that, when it is exceeded, negatively affects consumer behavior [61-63]. Therefore, by presenting products in a simple manner without excessive variety, sellers improve their customers' shopping experience [60], thus facilitating the choice process [64] and further improving satisfaction [65]. Thus, we propose the following:

P1: Ease of purchase positively influences consumers' intention to purchase healthy foods during the COVID-19 pandemic.

Many researchers consider that the fear of potentially being infected with COVID-19 is another component affecting consumer behavior when shopping in supermarkets [66,67]. In theory, fear amplifies the damage resulting from the disease, and the sudden onset of COVID-19 around the world caused fear, leading to stigma in some cases [66,68-70]. Recent research confirms that fear is directly associated with the rate and means of COVID-19 
transmission (i.e., rapidly and invisibly) and the morbidity and mortality it causes. When the level of fear is high, people may not think clearly and rationally. In this research, we propose that this has a moderating effect on the relationship between ease of purchase and the intention to buy healthy foods.

P2: During the pandemic, fear of contracting COVID-19 moderates the relationship between the ease of purchase and the intention to buy healthy foods.

Finally, the research model connecting all of the hypotheses is illustrated in Figure 1. The model has five constructs, four research hypotheses, and two propositions.

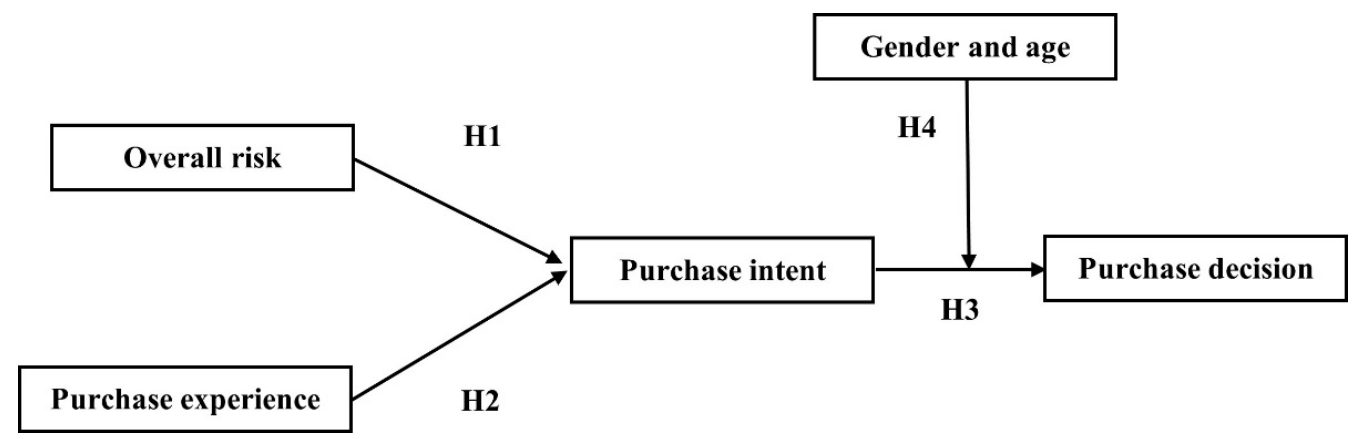

Figure 1. Proposed theoretical model.

\section{Empirical Study}

\subsection{Study Context}

To test the model, we collected data from people who regularly frequented major food retailers (at least once a fortnight). A survey was delivered directly to consumers entering and leaving stores from 2 May to 20 July 2020. In this period, Saudi Arabia experienced the intense first wave of the COVID-19 crisis, with the alert and caution of public health authorities at its peak (Figure 2). We interviewed 20 people who regularly (at least once a fortnight) frequented predominantly food-selling stores. These participants were in diverse socioeconomic categories (Appendix A). In this exploratory stage, to process the data collected, we had to specify our empirical dimension, clarify the concepts used, finalize the proposed hypotheses, and facilitate the subsequent operationalization of the explanatory variables. The use of semi-structured interviews is strongly recommended in the literature for collecting rich information. Moreover, interviews are an effective means of collecting data from the conscious or unconscious attitudes of the individuals being interviewed.

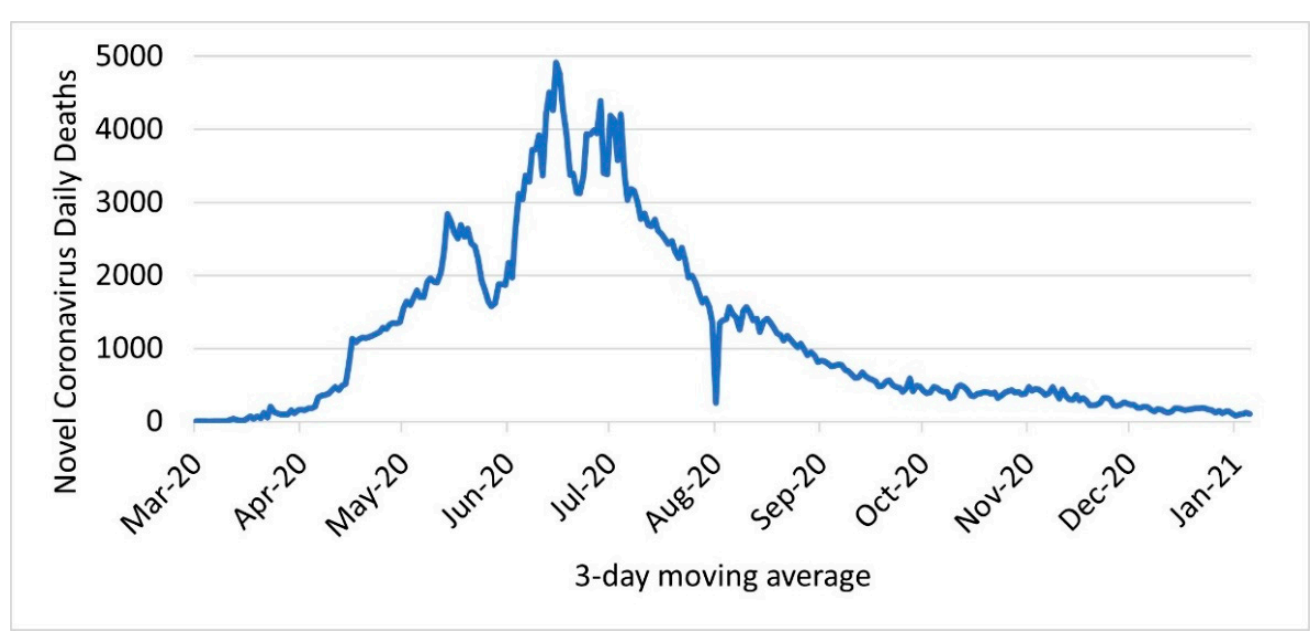

Figure 2. Daily new cases of COVID-19 in Saudi Arabia.

Second, we conducted a self-administered questionnaire survey at the entrance of supermarkets. We sought to measure causal relationships and verify cause-and-effect 
hypotheses. First, we translated the items adopted from the literature and adapted them to the Saudi context by performing a principal component analysis (PCA) on a sample of 100 people. Next, to obtain reliable and valid scales, we performed an exploratory and confirmatory analysis with 360 people while ensuring convergent and discriminant validity. To conduct the survey, we sought permission from the public authorities to administer the questionnaire to consumers frequenting the three largest stores in the small town of Bisha in the KSA (AlOthaim Market, AlRaya Super Market, and Hyber Panda Market). In addition, we received authorization from each store to conduct the survey in front of their premises while respecting the hygiene conditions imposed by the municipal authorities (wearing masks, using hand sanitizer, measuring skin temperature, etc.). The questionnaire was administered after verifying that the respondent (the store customer) was also complying with all hygiene conditions. The questionnaire was administered face-to-face and there were no open questions, because this was deemed too risky in the prevailing conditions at the time. However, face-to-face interviews were more relevant, because respondents were in the real situation, which ensured the collection of good-quality data. For each interviewee, we started by asking a filter question that allowed us to focus on consumers of healthy foods. Finally, despite only being allowed to carry out the survey for two hours a day, we approached 1152 people, 360 of whom were consumers of healthy foods. Of these 360 people, $46 \%$ were male and $54 \%$ were female.

\subsection{Survey Design and Data Collection}

Using SPSS-21 software, exploratory analysis made it possible to purify the scales, and this was supplemented with confirmatory factor analysis using AMOS-21 software to obtain reliable and valid scales. In addition, the hypotheses were validated through secondgeneration multivariate analysis (structural equations and binary logistic regression). The sample was chosen using nonprobability sampling, specifically convenience sampling. This choice ensured that there was a good-quality relationship between the interviewer and interviewee [71]. The validation of the conceptual model made it possible to verify our research hypotheses. Data collection was achieved according to the following sequence: (i) a test survey of 20 individuals (Appendix A), followed by (ii) an exploratory survey of 100 individuals and (iii) a final survey of 360 respondents.

Furthermore, when we examined the data, we did not find any careless responses, such as giving the same response to all questions. We therefore did not exclude any responses and used all 360 responses to test our research model. Approximately $54 \%$ of respondents were female; $5 \%$ were younger than 25 years old, $8 \%$ were between 26 and 34 years old, $24 \%$ were between 35 and 44 years old, $43 \%$ were between 45 and 54 years old, and the remaining $5 \%$ were older than 55 years.

\section{Data Analysis and Results}

\subsection{Qualitative Study}

We proposed several items for all the measurement scales, which used vocabulary and expressions from the responses of the consumers we questioned. As advocated by [71,72], we sought to avoid any controversy between analyzing the subjects and interpreting their responses. We therefore carried out a careful study of the collected data to extract the necessary information and ideas, as recommended by the traditional norms for qualitative analysis in marketing [73,74]. Next, we sought an interpretative approach aimed at identifying the results while avoiding any subjectivity in terms of the modern trends of qualitative analysis in social science and marketing $[75,76]$. Thus, our exploratory qualitative study made it possible to consolidate the hypotheses derived from our review of the literature. In addition, we verified the compatibility of the proposed hypotheses with the research problem, thus strengthening the research design for the operational phase of the empirical study.

We processed the data using hand-run semantic analysis, performing empirical, lexi$\mathrm{cal}$, and utterance analyses. This reinforced the relationships highlighted in the literature. 
Next, through an analysis of the sample's responses, we sought other variables that affect consumption behavior during the pandemic, such as fear of COVID-19 and ease of purchase.

\subsection{Quantitative Study}

Regarding the relationship between the fear of catching COVID-19 and the age and gender of respondents, the descriptive statistics showed surprising results: approximately $90 \%$ of women were very afraid of catching COVID-19, and the level of fear increased with age. For example, $100 \%$ of women over 55 said they were afraid of the coronavirus, compared with $81 \%$ of similarly aged men. What is more, $96 \%$ of women between 45 and 54 years of age declared a fear of coronavirus, compared to $66 \%$ of men in the same age range. This was under conditions when the country was recording more than 4000 positive COVID-19 cases per day for two months (Figure 2). Men were clearly less afraid than women, and women took more precautions than men.

Figure 3 shows the study process for all hypotheses and propositions, and it clarifies and summarizes the choice of models, logistic regressions, and tests for the moderating effects of the variables. Our procedure was conducted through a two-step analysis process: (i) exploratory factor analysis to purify the measurement scales, structural equations, and binary logistic regression and (ii) multi-group analysis to validate the hypotheses. The procedure for purifying the measurement scale was aimed at checking the dimensionality of the measurement scales and the reliability of each construct; this was made possible by using the Bartlett sphericity test, which must be significant (Bartlett significance $<5 \%$ ).

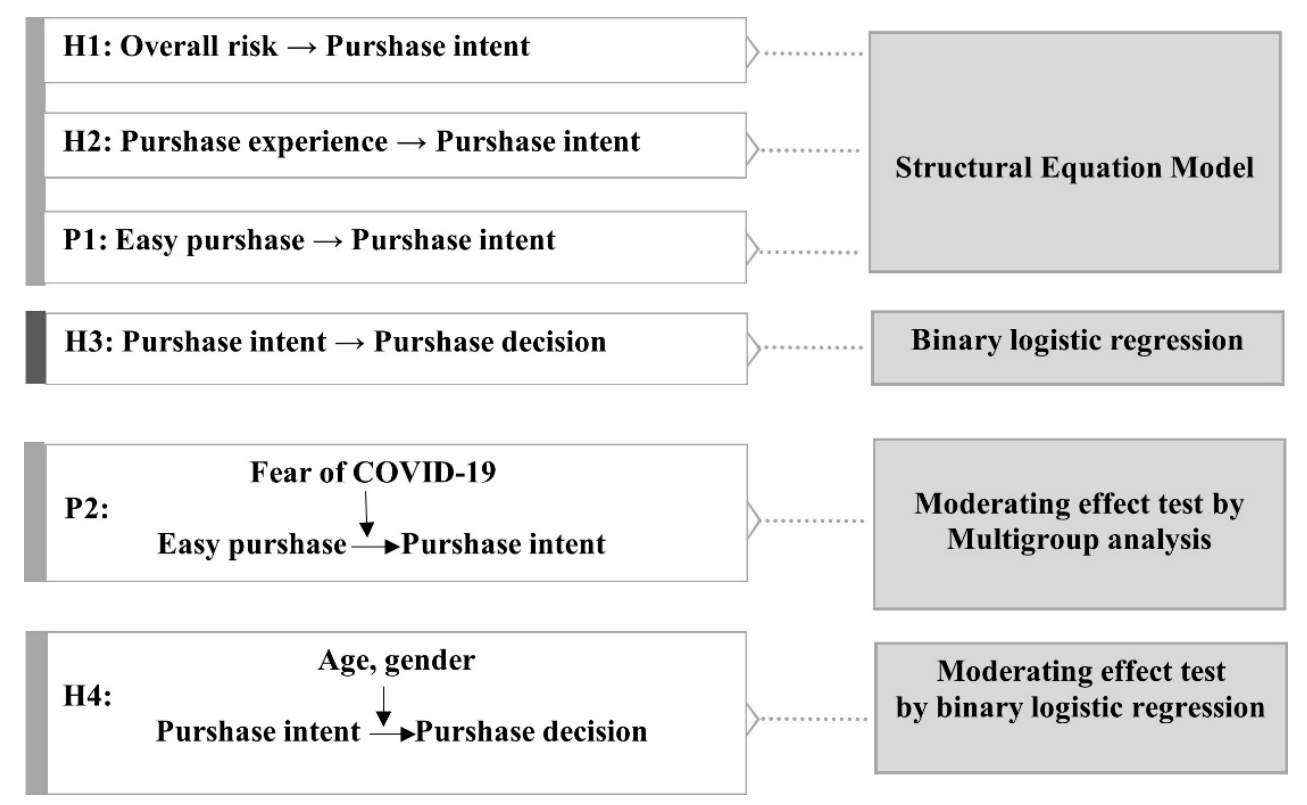

Figure 3. Statistical study of hypothesis testing.

To choose the axes, we examined the percentage of total returned variance. To analyze the reliability, we calculated Cronbach's alpha $\left(\alpha \_i\right)$ for each dimension as a reliability indicator. $\alpha \_i$ estimates the internal consistency between items, and if $0.7 \leq \alpha \_i \leq 1$, the variables related to this component have the same value, thus ensuring the internal consistency of the items. Finally, at the exploratory and confirmatory level, purification of the scales gave satisfactory results in accordance with $\alpha \_i$, Jöreskog's rho $(\rho)$, and average variance extracted ( $\rho_{-} \mathrm{vc}$ ) (i.e., $\left.0.7 \leq \alpha \_i \leq 1 ; \rho \geq 0.8 ; \rho_{-} \mathrm{vc} \geq 0.5\right)$. The five scales measuring the five constructs were, therefore, retained during this preliminary study. Following this purification, the study constructs were judged to exhibit a good level of internal consistency (Table 1). 
Table 1. Fit indices of global measurement model.

\begin{tabular}{cccc}
\hline \multicolumn{2}{c}{ Parsimonious Indices } & \multicolumn{2}{c}{ Incremental Indices } \\
\hline chi-square & $15,027.508$ & NFI & $0.901^{* * *}$ \\
Ddl & 376 & TLI & $0.903^{* * *}$ \\
$p$-value & 0.000 & CFI & $0.906^{* * *}$ \\
chi-square/ddl & 4.095 & & \\
GFI & $0.906^{* * *}$ & & \\
AGFI & $0.842^{* *}$ & & \\
RMR & $0.057^{* * * *}$ & & \\
RMSEA & $0.073^{*}$ &
\end{tabular}

To validate the measurement model, we performed a preliminary analysis to test the hypotheses. This involved applying factor analysis to all constructs integrated into the theoretical model, such that an indication of quality for the global model would justify its application to the empirical data.

Our results indicated stability for the overall model, so our sample was also stable (Table 1). Moreover, the normalized value of chi-square $\left(x^{2} / \mathrm{ddl}\right)$ was acceptable $\left(\mathrm{x}^{2} / \mathrm{ddl}<5\right)$. Parsimonious and incremental indices also indicated acceptable overall quality for the measurements. The adjusted goodness-of-fit index (AGFI) was close to the threshold, with a value of 0.842 , thus indicating an acceptable quality of fit [77], while the RMR was tolerable. The root-mean-square error of approximation (RMSEA) value was less than 0.1 , indicating a tolerable quality of fit. Consequently, all indicators showed a good level of adequacy for the overall model.

To ensure the objectivity, economy, and generalization of the results, we used scales inspired by the literature [78]. First, the overall risk scale is widely used in the literature. Some authors do not aggregate various risks into one, because they believe that this destabilizes the scale [79], so they use an overall scale based on a global understanding of the risk $[80,81]$. Meanwhile, a scale was proposed in [82] that is feasible for all distribution channels. This overall risk scale has six items and is based on a seven-point Likert scale, ranging from "not at all likely" to "very likely". For this scale, we obtained an original $\alpha \_i$ of 0.696 . Second, the purchasing experience scale, developed by $[83,84]$, comprises four factors (sense, feel, think, act), with each factor having three items. It is based on a five-point Likert scale (from "completely disagree" to "completely agree"). In our case, the original $\alpha \_i$ was 0.875 . Third, the intention-to-buy scale, developed by [38], has three items based on a five-point scale ranging from "not at all likely" to "very likely". In our case, the original $\alpha \_i$ was 0.781 . Fourth, the ease-of-purchase scale was inspired by [85] regarding the difficulty of finding a good product and course preparation. Originally, the scale comprised eight items, but after purification, only five items remained. This is based on a five-point Likert scale ranging from "strongly disagree" to "strongly agree." For our study, the original $\alpha \_i$ was 0.902 . Fifth, the fear of COVID-19 scale, developed by [67], has a unidimensional structure table with robust psychometric properties. The initial psychometric results indicated good properties from different types of testing (consumer culture theory (CCT) and Rasch analysis). Moreover, the overall score of the summed-up item scores can indicate the severity of the fear of COVID-19. In our case, the original $\alpha \_i$ was 0.718 .

After ensuring sufficient validity and reliability for the data, we tested our research model. Appendix B gives the estimation results of the global model and shows that the model validity conditions are satisfied for the five constructs through their internal consistency coefficients, showing high values and average extracted variance coefficients greater than 0.5 ( $\left.\rho_{-} v c_{-} \_a v e r a g e=0.703\right)$. Consequently, the indicators used to measure the constructs are correlated, and they converge through the reliability measurement values and/or variances between the constructs and their items. Regarding discriminant validity, a comparison between the correlation indices of the constructs and their shared variances allows us to conclude that the instrument used is specific to what we are currently measur- 
ing and that the construct correlates with its measures (indicators or manifest variables) and other constructs (latent variables). This is in accordance with the results of [86]. Indeed, according to those authors, validity is justified only if the different dimensions are relevant and distinct from one another. In addition, in theory, there are several approaches to determine discriminant validity, and in this work, we refer to that in [87], which involves checking that, for each factor, $\rho_{-}$vc is greater than the square of the correlations between the factors. The results prove that the constructs are sufficiently discriminated against each other (Table 2). Indeed, the average correlation of the latent variable with its manifest variables is globally greater than the square of the correlations. Consequently, the scales used in this study were deemed to be validated, and this allowed us to subsequently verify the previously postulated hypothetical relationships.

Table 2. Matrix of interconstruct correlations.

\begin{tabular}{|c|c|c|c|c|c|}
\hline & Overall Risk & Purchase Experience & Purchase Intent & Easy Purchase & Fear of COVID-19 \\
\hline Overall risk & 0.641 * & & & & \\
\hline Purchase experience & $0.022 *$ & $0.719 * * *$ & & & \\
\hline Purchase intent & $0.503^{* *}$ & $0.081^{* *}$ & $0.714 *$ & & \\
\hline Easy purchase & $0.591 *$ & $0.025 *$ & $0.501 * *$ & $0.709 *$ & \\
\hline Fear of COVID-19 & $0.430^{* * *}$ & 0.004 * & $0.515 * *$ & $0.494^{* *}$ & $0.731^{* *}$ \\
\hline
\end{tabular}

Note: ${ }^{* * *} p<0.001 ;{ }^{* *} p<0.01 ;{ }^{*} p<0.05$.

To test each hypothesis, the structural model we estimated included an endogenous dependent variable and a single exogenous variable, as presented in the following general form (Equation (1))

$$
\eta=\gamma \xi+\zeta
$$

where $\eta$ indicates the endogenous variable, $\gamma$ is the estimated regression coefficient, and $\xi$ and $\zeta$ are, respectively, the endogenous variable and the error term of the dependent variable (fit quality).

To test the moderating effect of individual variables (age and gender) on how the fear of COVID-19 influences the intent to buy healthy foods, we carried out a multi-group analysis. In the first step, we tested the moderating role of the fear of COVID-19 on the relationship between ease of purchase and intent to buy. Next, we (i) identified the groups of consumers and (ii) checked whether the correlations between the two constructs and their measurement variables significantly differed from one group to another. As the fear of COVID-19 is a latent variable composed of seven items, we performed PCA and then recorded the factor scores of the individuals. Finally, we built the groups based on the median. This procedure allowed us to divide the fear of COVID-19 variable into two groups, low-level fear and high-level fear. SPSS-21 software made it possible to identify two subsamples: a group of people with a relatively low level of fear of COVID-19 (108 individuals) and a group with a relatively high level of fear (252 individuals).

As described in [51], a third variable can play such a role if and only if there is a significant interaction between the explanatory variable (intention to purchase) and the potential moderator (gender and age in our case) on the variable to be explained (purchasing decision). Under these conditions, the logistic regression model assumes the following expression (Equation (2))

$$
P D=\beta \_0+\beta \_1(P I \times P)+\beta \_2(P I \times A \times P)+\beta \_3(P I \times S \times P I)
$$

where PD is the purchasing decision, $\beta \_0$ is a constant, and $\beta \_1, \beta \_2$, and $\beta \_3$ are the coefficients reflecting the weights of variables in the total explanation of the logistic model. $\mathrm{PI}$ is the intent to buy, $\mathrm{P}$ is the purchase, and A and S are, respectively, the age and gender of the consumer. Figure 4 shows the results. 


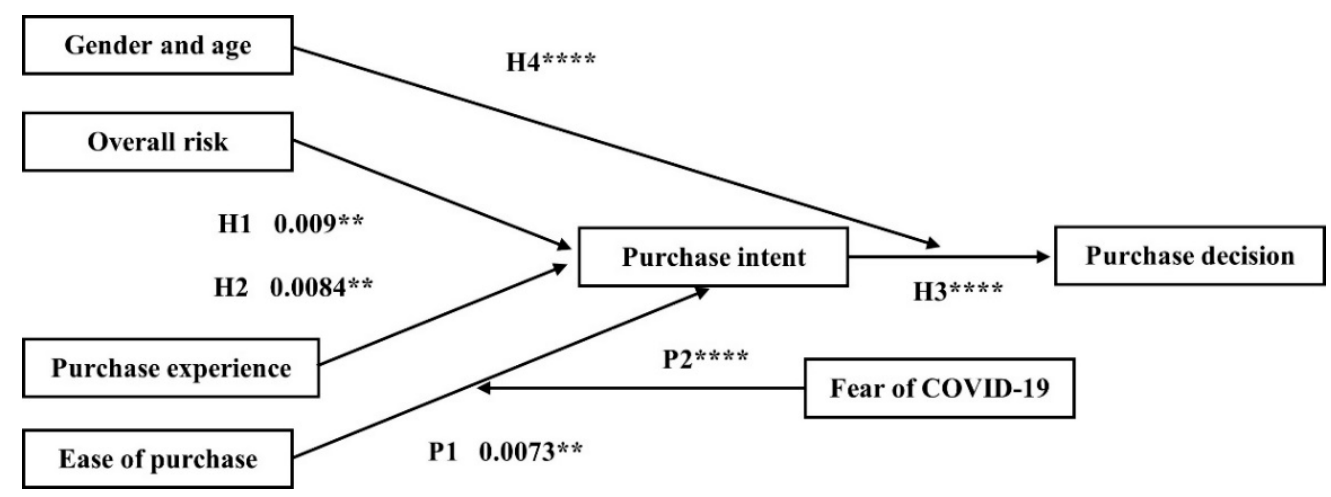

Figure 4. Structural model results. Note: ${ }^{* * *}$ assumptions and propositions concerning moderating variables ( $\mathrm{H} 4$ and $\mathrm{P} 2)$ and/or relations between endogenous and exogenous variables (H3). ** $p<0.01$.

\section{Discussion}

\subsection{Key Findings Based on Hypothesis Tests}

The structural model (Equation (1)) shows a good fit to the data (Table 3). Indeed, the level of the indices ranges from good to excellent (GFI > 0.9; AGFI > 0.9; RMSEA $=0.069$ ), and the incremental indices show the good quality of the model. Thus, the results of the estimation of structural equations prove that there is a significant relationship between the intention to buy and overall risk. This risk is, therefore, negatively $(\gamma=-0.136)$ and significantly $(\mathrm{CR}=4.071 ; p<0.05)$ related to purchasing intention during the COVID-19 crisis (Table 4), so H1 is supported. For H2, our structural model has a good fit with the data (Table 3), and all the parsimonious and incremental indices (GFI > 0.975; AGFI > 0.937; RMSEA $=0.074$ ) indeed reinforce the good quality of the model. Structural equation estimations also prove that there is a significant relationship between purchasing experience and intention to buy: intention to buy is positively $(\gamma=0.210)$ and significantly $(C R=9.531$; $p<0.05$ ) related to the shopping experience (Tables 2 and 3 ), so $\mathrm{H} 2$ is also supported. For $\mathrm{P} 1$, the data have good fitting qualities (Table 3 ), and all the indices indicate excellent model quality $(\mathrm{GFI}>0.977$; AGFI > 0.945; RMSEA $=0.065)($ Table 3$)$. Then, the results of structural equation estimation confirm a significant relationship between intention to purchase and ease of purchase: ease of purchase is positively $(\gamma=0.308)$ and significantly $(C R=3.071$; $p<0.05$ ) related to intention to purchase (Table 4), so P1 is supported.

Table 3. Overall risk, purchase experience, and ease of purchase during COVID-19 pandemic and their effects on intention to purchase (fit indices of structural model).

\begin{tabular}{ccccccccc}
\hline & $\mathbf{x}^{2} / \mathbf{d d l}$ & GFI & AGFI & RMR & RMSEA & NFI & TLI & CFI \\
\hline H1 & 3.266 & 0.958 & 0.928 & 0.006 & 0.069 & 0.983 & 0.985 & 0.989 \\
H2 & 3.578 & 0.975 & 0.937 & 0.010 & 0.074 & 0.990 & 0.98 & 0.993 \\
P1 & 3.001 & 0.977 & 0.945 & 0.068 & 0.065 & 0.973 & 0.965 & 0.981 \\
\hline
\end{tabular}

Table 4. Overall risk, purchase experience, and ease of purchase during COVID-19 pandemic and their effects on purchase intention (structural model).

\begin{tabular}{cccccc}
\hline & $\mathbf{x}^{2} / \mathbf{d d l}$ & $\gamma$ & SE & CR & $p$-Value \\
\hline H1 & (Purchase intentOverall risk) & -0.136 & 0.033 & 4.071 & 0.000 \\
H2 & (Purchase intentPurchase experience) & 0.210 & 0.022 & 9.531 & 0.000 \\
P1 & (Purchase intentEasy purchase) & 0.308 & 0.100 & 3.071 & 0.002 \\
\hline
\end{tabular}

$\mathrm{H} 3$ assumes that the intention to purchase has a positive effect on the decision to purchase healthy foods during the COVID-19 pandemic. An examination of this relationship is possible through a binary logistic regression of all the variables. We then tested 
the following hypothesis: The greater the intention to buy, the more likely consumers will decide to purchase healthy foods. This makes it possible to verify consumer behavior when deciding between purchasing (1) and not purchasing (0). Empirically, the model's quality is satisfactory, because $58.31 \%$ of respondents ${ }^{\prime}$ statements are split between buyers and non-buyers. The goodness-of-fit indicators $(\chi 2$ model $=20.810 ; \mathrm{ddl} / \chi 2=2 ;<0.05)$ show that the model is significant (Table 5).

Table 5. Effect of purchase intention on purchasing decision.

\begin{tabular}{|c|c|c|c|c|c|}
\hline \multicolumn{6}{|c|}{ Classification } \\
\hline Purchase & \multicolumn{5}{|c|}{39.4} \\
\hline No purchase & \multicolumn{5}{|c|}{60.6} \\
\hline$\%$ correct overall & \multicolumn{5}{|c|}{58.31} \\
\hline \multicolumn{6}{|c|}{ Fit quality } \\
\hline \multirow[t]{12}{*}{ Model } & & $\begin{array}{c}\text { chi-square: } \\
20.810\end{array}$ & & & \\
\hline & Model & ddl: 2 & & & \\
\hline & & p: 0.000 & & & \\
\hline & Hosmer-Lemeshow & HL: 12.456 & & & \\
\hline & & ddl: 6 & & & \\
\hline & & p: 0.111 & & & \\
\hline & Cox \& Snell R ${ }^{2}$ & 0.072 & & & \\
\hline & Nagelkerke $\mathrm{R}^{2}$ & 0.089 & & & \\
\hline & Variables of equation_1 & & & & \\
\hline & & $\beta$ & Wald & Sig. & $\operatorname{Exp}(\beta)$ \\
\hline & Purchase intent & 0.229 & 12.250 & 0.000 & 1.348 \\
\hline & Constant & -0.404 & 0.775 & 0.000 & 0.667 \\
\hline
\end{tabular}

The goodness-of-fit test divided the subjects into deciles based on the predicted probabilities, and then we calculated a chi-square from the observed and expected frequencies. A $p$-value of 0.111 was calculated from a chi-square with six degrees of freedom. This value is greater than 0.05, implying that the model's estimates adjust to the data to an acceptable level [88]. Cox and Snell's $\mathrm{R}^{2}$ and Nagelkerke's $\mathrm{R}^{2}$ confirm the relationship between the dependent and independent variables. The model, therefore, explains $8.9 \%$ of the variance of the dependent variable. This result is acceptable, if not strong enough, but it proves that the model has a good fit. Table 5 allows an evaluation of the contribution of each variable (purchase intent, purchase decision) in explaining the choice between purchasing and not purchasing. The $\beta$ coefficient also makes it possible to compare the relative weights of the variables as follows: when the absolute value of a coefficient is high, the corresponding variable is increasingly important in explaining the model. On the other hand, a negative $\beta$ means that the variable has more influence on the decision to not make a purchase. However, the analysis of the $\beta$ coefficients did not allow us to measure the influence of each variable, so, for this, we worked with the odds ratio $\operatorname{Exp}(\beta)$, which facilitates an easier interpretation of the results.

Table 5 shows that purchase intention has a significant and positive effect $(\beta=0.229$; $\chi 2$ de Wald $=12.250 ; p=0.000$ ). In addition, the Wald coefficients were significant, allowing us to finally interpret the results and conclude that the logistic regression we carried out fully affirms H3.

Regarding the test for the moderating effect of age and gender on the relationship between the fear of COVID-19 and the intention to purchase healthy foods, the results validate the propositions. Indeed, Table 6 shows that the calculated difference in chi-square values is not significant at the $5 \%$ level. Thus, the correlations between the constructs and their measurement variables are not significantly different from one group to another, proving that the two models are "equivalent" or "stable" because the measurement parameters between the two groups of people are invariant. 
Table 6. Chi-square difference tests between free model and constrained models 1 and 2.

\begin{tabular}{cccccccccc}
\hline \multicolumn{2}{c}{ Chi-Square Difference Tests } & \multicolumn{2}{c}{ Free Model } & \multicolumn{3}{c}{ Constrained Model 1 } \\
\hline Chi-square & $\mathrm{ddl}$ & $p$ & Chi-square & ddl & $p$ & Chi-square & ddl & $p$ \\
\hline \multicolumn{9}{c}{ Correlations between the two constructs and their measurement variables } \\
\hline 6.069 & 9 & 0.733 & 415.461 & 86 & 0.000 & 421.530 & 95 & 0.000 \\
\hline \multicolumn{8}{c}{ Confirmatory analysis } \\
\hline 6.157 & 1 & 0.013 & 421.530 & 95 & 0.000 & 427.686 & 96 \\
\hline
\end{tabular}

Finally, during the confirmatory analysis, we compared the chi-square value of a free model (where one parameter is not equal between the two groups) with the chi-square value of a constrained model (where all parameters are equal between the two groups). If, between the two models, the difference in chi-square value is significant, the variable has a moderating effect.

Examining the regression coefficients and the significance of the link between the standardized coefficients helps to provide a clear idea of the direction of influence for the moderating variable. Table 7 shows that the chi-square difference test is significant, so the free model has greater explanatory power than the constrained model. This indicates that the fear of COVID-19 has a moderating effect on the relationship between the intention to purchase and the ease of purchase. By applying the "step-by-step downward plausibility" method, the variables that significantly influence the purchasing decision, whether directly or through an interaction with intention to purchase, will appear. Table 7 summarizes only the significant influence relationships, whether direct or through interactions. The regression of Equation (2) confirms the direct influence of intention to purchase on purchasing decision, and a person's age and gender were found to be moderators of the relationship between intention to buy and purchasing decision (Table 8). Therefore, $\mathrm{H} 4$ is supported. In addition to the moderating role of these two variables (age and gender), they are also quasi-moderating variables (Table 9 ). Indeed, $72.5 \%$ of purchases made during the COVID-19 period can be explained through consumers' intention to purchase, age, and gender (Nagelkerke's $\mathrm{R}^{2}=72.1 \%$ ). Our results, therefore, confirm that age and gender directly influence the completion of a purchase, so these two variables play the role of quasi-moderators. Table 10 summarizes all of the obtained results.

Table 7. Multi-group analysis of moderating effect of fear of COVID-19.

\begin{tabular}{ccccccc}
\hline & \multicolumn{2}{c}{ Low Fear of COVID-19 } & & \multicolumn{2}{c}{ High Fear of COVID-19 } \\
\hline & $\begin{array}{c}\text { Standard } \\
\text { Coefficient }\end{array}$ & RC & $p$ & $\begin{array}{c}\text { Standard } \\
\text { Coefficient }\end{array}$ & RC & $p$ \\
\hline $\begin{array}{c}\text { P2: } \\
\text { (Purchase intent }+- \text { Easy purchase) }\end{array}$ & 0.057 & 3.264 & 0.001 & 0.024 & 1.557 & 0.119 \\
\hline
\end{tabular}

Table 8. Binary logistic regression of purchase decision (interaction effects).

\begin{tabular}{cccccc}
\hline & $\boldsymbol{\beta}$ & E.S & Wald & ddl & Sig \\
\hline Purchase intent & 2.121 & 0.712 & 21.225 & 1 & 000 \\
(Purchase intent $\times$ Purchase) & 0.443 & 0.172 & 5.671 & 1 & 0.008 \\
(Purchase intent $\times$ Age $\times$ Purchase) & -0.141 & 0.109 & 4.316 & 1 & 0.012 \\
(Purchase intent $\times$ Sex $\times$ Purchase) & 0.221 & 0.068 & 7.681 & 1 & 0.009 \\
Constant & -8.198 & 1.053 & 28,698 & 1 & 000 \\
\hline
\end{tabular}

Cox and Snell $R^{2}=58.3 \%$; Nagelkerke $R^{2}=72.1 \%$ 
Table 9. Binary logistic regression of purchase decision (direct effects).

\begin{tabular}{cccccc}
\hline & $\boldsymbol{\beta}$ & E.S. & Wald & ddl & Sig \\
\hline Purchase intent & 2.385 & 0.531 & 35.171 & 1 & 000 \\
Age & -0.523 & 0.268 & 4.568 & 1 & 0.03 \\
Gender & 0.343 & 0.182 & 5.551 & 1 & 0.00 \\
Constant & -10.1812 & 2.864 & 21.567 & 1 & \\
\hline
\end{tabular}

Cox and Snell $\mathrm{R}^{2}=55.3 \%$; Nagelkerke $\mathrm{R}^{2}=72.51 \%$

Table 10. Results.

\begin{tabular}{|c|c|c|}
\hline \multicolumn{3}{|c|}{ Hypotheses for Direct Effects } \\
\hline Hypothesis & Hypothesis test method & Result \\
\hline H1: Overall risk $\rightarrow$ Purchase intent & SEM & validated \\
\hline $\mathrm{H} 2$ : Purchase experience $\rightarrow$ Purchase intent & SEM & validated \\
\hline P1: Easy purchase $\rightarrow$ Purchase intent & SEM & validated \\
\hline H3: Purchase intent $\rightarrow$ Purchase decision & BLR & validated \\
\hline \multicolumn{3}{|c|}{ Hypothesesfor moderating effects } \\
\hline \multicolumn{3}{|l|}{ Fear of COVID-19 } \\
\hline $\mathrm{P} 2: \downarrow$ & MA & validated \\
\hline \multicolumn{3}{|l|}{ Easy purchase $\rightarrow$ Purchase intent } \\
\hline \multicolumn{3}{|l|}{ Age, gender } \\
\hline $\mathrm{H} 4: \downarrow$ & BLR & validated \\
\hline Purchase intent $\rightarrow$ Purchase decision & & \\
\hline
\end{tabular}

Note: SEM, structural equation model; BLR, binary logistic regression; MA, multigroup analysis.

\subsection{Theoretical Implications}

We present six theoretical implications of these findings. First, in contrast to recent studies of specific aspects of consumer behavior during the COVID-19 pandemic, we integrated several variables related to consumer behavior during times of crisis and empirically show how these behavioral variables interact to stimulate purchasing decisions and influence the purchasing process during a pandemic. Second, the results emphasize that when the risks of consumption are high for consumers, they have a lower intention to purchase and may no longer risk making a purchase. If the consumer is experienced with and accustomed to shopping in department stores, purchasing healthy foods during the COVID-19 pandemic will be faster and more intensive. Consumers of healthy foods are quick to obtain and consume these desirable goods because their intention to purchase positively influences their purchasing decisions. Indeed, previous researchers mostly investigated the role of such variables in the purchasing process, but with less precision, especially in a time of crisis. Furthermore, to the best of our knowledge, this is the first study to investigate how consumer behavior variables operate during a pandemic, such as the COVID-19 crisis in Saudi Arabia.

Third, unlike in previous studies, which investigated the roles of age and gender in people's responses to the COVID-19 pandemic and showed that people have different levels of concern about the disease and modify their behavior according to their gender and age $[33,37]$, we empirically show that these two variables play a role in moderating the relationship between the fear of COVID-19 and intention to purchase. Indeed, consumers of healthy foods do not take long to obtain and consume these goods, because their intention to buy positively influences their purchasing decisions, and their gender and age are "quasimoderators" of the relationship between the intention to buy and actually buying healthy foods in supermarkets. However, several research studies focused on the mental health of individuals during the COVID-19 crisis, and psychologists in particular have examined anxiety disorders as a major risk related to epidemic situations (fear that they or loved ones 
will catch the disease) and living conditions in lockdown (social isolation, loss of income, frustration, etc.). This study expands the existing research into consumer behavior.

Fourth, we used rigorous measurement instruments and justified the choice of the different scales used from a conceptual viewpoint. These scales were relatively short so as to avoid respondents becoming weary, and the expressions were carefully adapted to the Saudi context through a PCA conducted among a sample of 100 people. This made it possible to adapt the items to the actual context, which is characterized by the excessive consumption of sweet and fatty foods. Fifth, our qualitative study is globally important, because it enabled us to determine the moderating role of personal sociodemographic variables like age and gender [37]. Sixth, our research contributes to the managerial literature on developing marketing strategies, so actors involved in the mass distribution of healthy foods can learn how consumers of those foods behave and modify their behavior.

Our results, therefore, help to understand consumer behavior during a health crisis, and they show that it is important for retailers to develop their points of sale and adapt their assortments with logical category management, because these will facilitate consumers purchasing process, and therefore help them to reduce the time they spend shopping.

In addition, these results extend previous research into consumption risks [2,23-30] and changes in attitudes during times of crisis [30-32]. They also enrich the literature about the effects of experiential marketing on the purchasing experience [34,35] and purchasing intentions $[38,39,47,48]$, the impact of ease of purchase on purchasing decisions [66-70], and the effects of contamination fear on consumer behavior [21,22,67] and the purchasing experience $[31,34-36,43,46,60,64,65,83,84]$. In this sense, this research helps to understand the various elements of consumer behavior in the face of the COVID-19 crisis, and contributes to the development of an important debate about which marketing strategies and tactics retail companies should adopt. Finally, this research provides reliable measurement tools that will be useful for marketers during the design phase of a marketing strategy during a crisis.

\subsection{Practical Implications}

It is expected that Saudi Arabia will soon enter a second wave of the COVID-19 pandemic. As of 31 December 2020, it recorded 362,601 cumulative cases and 6214 cumulative deaths [1], which are both significantly more than previously expected [19]. As in many other places in the world, the Saudi public authorities imposed strict limitations on the movements and gatherings of its citizens to contain and suppress the spread of COVID-19 [3,4,8,21]. However, aside from some compulsory closures, the country has not imposed strict measures on sales areas, especially supermarkets. For example, how many people should be allowed in a particular area so that buyers can maintain sufficient social distancing has not clearly been defined. Our results demonstrate that the most cautious consumers confirmed that their purchasing process under such conditions had been disrupted by the fear of COVID-19 during the first wave of the pandemic. Most said that they would continue to adapt their behavior when the country enters a second wave.

This study's results support previous work about changes in the purchasing decision process during a health crisis, consumer behavior during purchasing, and health-risk mitigation behaviors [23-25,31,32]. They also support previous contributions about consumer caution amid rising contagion because consumers are confronting goods in stores $[10,19,21]$. This health pandemic has had direct and indirect effects on consumers' lifestyles, purchasing power, desires, and general consumption of goods and services [11-13]. Previous studies have included changes in people's relationships with food quality and food use and a growing preference for healthy foods $[22,36]$. The rising consumption risks have effects on purchasing [23-25], such as physical risk [2,26-29] and financial risk [30], and this influences consumers' attitudes and behavior in a time of crisis [30-32]. Experiential marketing can also contribute to the purchasing experience [34,35].

These practical implications indicate that retailers can anticipate unusual consumer behavior during a health crisis, and these changes in behavior can be determined by 
different levels of fear of contamination according to the consumer's age and gender. Although our focus was not primarily on creating or adapting measurement scales, the variables we used were developed based on the extensive literature. We also performed exploratory factor analyses followed by confirmatory factor analysis in the validation phase to verify convergent and discriminant validity.

\subsection{Limitations and Future Research}

We would like to emphasize four limitations of our research. First, the collected data reflected the situation in a country that was heavily impacted by active COVID-19 cases. The country had prepared for the situation by closing schools, restaurants, and public services, and this may have sparked fears of upcoming disruption and triggered people's behavioral responses. Second, from a theoretical viewpoint, another limitation concerns the conceptual model and the survey method. Indeed, we questioned consumers in front of large stores in a time of crisis, and the answers provided may be biased and may not accurately reflect real consumer behavior. Therefore, the observation or "list before, list after" method might have better reflected the reality of consumer behavior. Third, from a methodological viewpoint, the data collection was time-constrained, and we were unable to survey more people in the various regions of Saudi Arabia, which makes the results difficult to generalize. Fourth, we only considered situational variables that could have given a better explanation of consumer behavior during the COVID-19 crisis. Thus, the failure to consider other variables linked to consumer choice, such as time pressure, the attractiveness of available options, the flexibility of the environment, and so on, limit the usefulness of our results. Consequently, these limitations should be considered when interpreting the results, and for all of these reasons, we recommend that future research take the indicated limitations and research gaps into consideration.

\section{Conclusions}

Research continues to explain the profound changes in consumer behavior since the onset of this crisis from a psychological perspective. From the same perspective, we collected data from Saudi respondents $(n=360)$ regarding their consumption of healthy foods during the first wave of the COVID-19 pandemic. In addition, we developed a quantitative and qualitative approach with the objective of modelling consumer behavior. We performed double modelling through (i) a structural equation model to explain the impact of three variables (purchasing experience, ease of purchase, and intention to purchase) on purchasing decisions and (ii) a binary logistic regression model to test the relationship between the intention to buy and purchasing decisions.

The empirical results suggest that women are more concerned than men about catching COVID-19. Indeed, most female respondents considered the novel coronavirus to present an imminent danger, and because they are so afraid of contamination, they take a lot more precautions than men do, especially when shopping. Furthermore, older people have a greater fear of infection when shopping; the youngest respondents, both male and female, were less afraid of coronavirus, so they took fewer precautions against contamination. However, all respondents reported a drop in their visits to shops, restaurants, and gathering places. Therefore, gender and age act as quasi-moderators in the relationship between the fear of COVID-19 and the intention to purchase. The fear of COVID-19 stems from the fact that these people care much more about their health than others' health, so they are more cautious about avoiding contamination.

It is, therefore, a priority for public decision-makers to take actions to maintain a minimum level of well-being and prevent the development of disorders in the population, because in the short term, this will reduce the demand on the health system and hospitals caused by an influx of people with symptoms of acute anxiety or stress, especially as Saudi Arabia prepares for a second wave of the pandemic. Indeed, during the first wave, consumption risks, such as performance, social, physical, financial, psychological, and time-loss risks, were amplified. The risks became greater and greater, so they negatively 
influenced the intention to purchase, and consumers gradually decreased their visits to stores. However, their buying experiences and intention to buy meant that they increased their purchases of healthy foods compared with other goods.

While our contributions support and build upon the results of previous research into strategic and tactical marketing decision-making, the lockdown and other government actions meant we investigated fewer people and therefore collected less information. Accordingly, we encourage scholars to take the opportunity to collect further empirical data about purchasing behavior during this crisis period, especially as the country will likely enter a second wave of the pandemic. Finally, while the number of positive COVID19 cases is now low in Saudi Arabia, on 7 January 2021, public authorities discovered the first 10 cases of a new variant of the virus.

Author Contributions: Conceptualization: H.R. and F.H.; methodology: H.R., N.K.S., and F.H.; software: N.K.S.; validation, formal analysis, investigation, resources, data curation, writing-original draft preparation, writing-review and editing, visualization: H.R., N.K.S., and F.H.; supervision, project administration: H.R. All authors have read and agreed to the published version of the manuscript.

Funding: This research received no external funding.

Institutional Review Board Statement: The study was conducted according to the guidelines of the Declaration of Helsinki, and approved by the Ethics Committee of the College of Business of the University of Bisha (the General Research Project under grant number UB-36-1441, approved on 17 December 2020).

Informed Consent Statement: Informed consent was obtained from all subjects involved in the study.

Data Availability Statement: Data is not publicly available, through the data may be made available on request from the corresponding author.

Acknowledgments: The authors are grateful to the Deanship of Scientific Research at the University of Bisha, Saudi Arabia, for funding this work through the General Research Project under grant number UB-36-1441.

Conflicts of Interest: The authors declare no conflict of interest.

\section{Appendix A}

Table A1. Sociodemographic Characteristics of the Qualitative Study Sample.

\begin{tabular}{|c|c|c|c|c|c|c|c|}
\hline Participant & Age & Gender & Profession & Participant & Age & Gender & Profession \\
\hline 1 & 38 & $\mathrm{~F}$ & $\begin{array}{c}\text { University } \\
\text { teacher }\end{array}$ & 11 & 35 & $\mathrm{~F}$ & Pharmacist \\
\hline 2 & 55 & M & Administrator & 12 & 62 & M & Retired \\
\hline 3 & 30 & $\mathrm{~F}$ & $\begin{array}{l}\text { Administration } \\
\text { secretary }\end{array}$ & 13 & 62 & $\mathrm{~F}$ & Retired \\
\hline 4 & 53 & $\mathrm{~F}$ & $\begin{array}{l}\text { Secondary } \\
\text { school } \\
\text { teacher }\end{array}$ & 14 & 26 & M & Student \\
\hline 5 & 31 & $\mathrm{~F}$ & Engineer & 15 & 44 & M & Employee \\
\hline 6 & 28 & $\mathrm{~F}$ & $\begin{array}{l}\text { Senior } \\
\text { technician }\end{array}$ & 16 & 35 & $\mathrm{M}$ & $\begin{array}{c}\text { Counter } \\
\text { agent }\end{array}$ \\
\hline 7 & 27 & $\mathrm{~F}$ & Architect & 17 & 40 & M & Doctor \\
\hline 8 & 22 & $\mathrm{~F}$ & Student & 18 & 30 & $\mathrm{M}$ & Nurse \\
\hline 9 & 26 & $\mathrm{~F}$ & $\begin{array}{l}\text { Bachelor } \\
\text { unemployed }\end{array}$ & 19 & 55 & M & $\begin{array}{l}\text { High school } \\
\text { director }\end{array}$ \\
\hline 10 & 32 & M & Paramedic & 20 & 40 & M & Administrator \\
\hline
\end{tabular}




\section{Appendix B}

Table A2. Survey Items and Their Loadings. Exploratory and Confirmatory Analysis of Constructs.

\begin{tabular}{|c|c|c|c|c|}
\hline Items & $\lambda_{\mathbf{i}}$ & $\rho$ & $\rho_{-\mathrm{vc}} \geq 0.5$ & $\alpha_{\mathbf{i}}$ \\
\hline Overall risk & & 0.926 & 0.641 * & 0.696 \\
\hline Performance risk: The quality of a healthy food may not meet expectations. & 0.862 & & & \\
\hline $\begin{array}{l}\text { Social risk: A healthy food you buy may give you a bad image in the eyes of } \\
\text { those around you. }\end{array}$ & 0.794 & & & \\
\hline $\begin{array}{l}\text { Physical risk: The use (or consumption) of a healthy food may be dangerous for } \\
\text { my health or that of those around me. }\end{array}$ & 0.771 & & & \\
\hline
\end{tabular}

Financial risk: The purchase of a healthy food may represent a bad expenditure (e.g., wasted money if not effective, greater cost than expected, possibility of obtaining an equivalent or better item at a lower price).

Psychological risk: Buying healthy food can lead to self-disappointment (i.e., disappointment in yourself due to a poor choice).

\subsection{8}

Risk of wasted time: Buying healthy food may be a waste of time for me.

$$
\text { Purchasing experience }
$$

Sense 1: This healthy food is focused on the sensory experience.

Sense 2: This healthy food does not try to engage my senses.

0.757

Sense 3: This healthy food tries to excite my senses.

Feel 1: This healthy food tries to put me in a certain mood.

Feel 2: This healthy food tries to be emotional.

Feel 3: This healthy food tries to be effective.

Think 1: This healthy food tries to intrigue me.

Think 2: This healthy food tries to stimulate my curiosity.

Think 3: This healthy food appeals to my creative thinking.

Act 1: This healthy food tries to make me think about my lifestyle.

Act 2: This healthy food tries to remind me of activities I could do.

Act 3: This healthy food tries to get me to think about my behavior. Intention to buy

If I were looking for a healthy food, I would consider this healthy brand as an option.

If I were looking for a healthy food, I would actually buy a product from this healthy brand.

Based on what I've experienced with this healthy brand, I am more likely to purchase this brand's products.

$$
\text { Ease of purchase }
$$

I find it easy to buy goods from this healthy brand.

It is hard to find what you want with this healthy food brand.

With this brand of healthy foods, I have a hard time finding what I need.

In this store, it is difficult to find the healthy foods that I am interested in.

With this brand, the presentation of the products is clear.

$$
\text { Fear of COVID-19 }
$$

0.938

$0.731^{* *}$

0.718

0.670

0.813

0.799

0.769

0.769

0.860

0.867

0.802

0.714

0.702

0.733

0.969

0.938

0.904

0.584

$0.714^{*}$

0.781

0.812

0.749

0.709 *

0.902

0.980

0.811

0.792

0.811

0.917

\begin{tabular}{ll}
\hline I am very afraid of COVID-19. & 0.713 \\
\hline It makes me uncomfortable to think about COVID-19. & 0.709 \\
\hline My hands become clammy when I think about COVID-19. & 0.818 \\
\hline
\end{tabular}


Table A2. Cont.

\begin{tabular}{|c|c|c|c|c|}
\hline Items & $\lambda_{\mathbf{i}}$ & $\rho$ & $\rho_{-\mathrm{vc}} \geq 0.5$ & $\alpha_{\mathrm{i}}$ \\
\hline I am afraid of dying from COVID-19. & 0.894 & & & \\
\hline $\begin{array}{l}\text { When watching the news and stories about COVID-19 on social media, I } \\
\text { become nervous or anxious. }\end{array}$ & 0.875 & & & \\
\hline I cannot sleep because I worry about getting COVID-19. & 0.855 & & & \\
\hline My heart races or palpitates when I think about getting COVID-19. & 0.859 & & & \\
\hline Mean & - & - & 0.703 & - \\
\hline
\end{tabular}

Note: ${ }^{* * *} p<0.001 ; * * p<0.01 ; * p<0.05$.

\section{References}

1. World Health Organization [WHO]. WHO Coronavirus Disease (COVID-19) Dashboard. 2020. Available online: https:/ / covid19. who.int/table (accessed on 23 October 2020).

2. World Health Organization [WHO]. Coronavirus Disease (COVID-19). 2020. Available online: https://www.who.int/ emergencies / diseases/novel-coronavirus-2019/question-and-answers-hub/q-a-detail/ q-a-coronaviruses?fbclid=IwAR2 FJnNv5678_FK9x31tMlGWRvYEORRKd7UyOmPnOMl5w3WP-YI_U8AKYNQ (accessed on 15 April 2020).

3. Islam, T.; Pitafi, H.; Wang, Y.; Aryaa, V.; Mubarik, S.; Akhater, N.; Xiaobei, L. Panic Buying in the COVID-19 Pandemic: A Multi-Country Examination. J. Retail. Consum. Serv. 2021, 59, 102357. [CrossRef]

4. Naeem, M. Do social media platforms develop consumer panic buying during the fear of Covid-19 pandemic. J. Retail. Consum. Serv. 2021, 58, 102226. [CrossRef]

5. Parteka, A. What drives cross-country differences in export variety? A bilateral panel approach. Econ. Model. 2020, 92, 48-56. [CrossRef] [PubMed]

6. World Bank [WB]. A Shock Like No Other: The Impact of COVID-19 on Commodity Markets. 2020. Available online: https:/ / www.worldbank.org/en/news/feature/2020/04/23/coronavirus-shakes-commodity-markets (accessed on 20 December 2020).

7. Zulfigarov, F.; Neuenkirch, M. The impact of oil price changes on selected macroeconomic indicators in Azerbaijan. Econ. Syst. 2020, 44, 100814. [CrossRef]

8. Prentice, C.; Chen, J.; Stantic, B. Timed intervention in COVID-19 and panic buying. J. Retail. Consum. Serv. 2020, 57, 102203. [CrossRef]

9. Kim, J.; Giroux, M.; Kim, J.E.; Choi, Y.K.; Jimenez, H.G.; Lee, J.C.; Park, J.; Jang, S.; Kim, S. The moderating role of childhood socioeconomic status on the impact of nudging on the perceived threat of coronavirus and stockpiling intention. J. Retail. Consum. Serv. 2020, 59, 102362. [CrossRef]

10. Poelman, M.P.; Gillebaart, M.; Schlinkert, C.; Dijkstra, S.C.; Derksen, E.; Mensink, F.; Hermans, R.C.J.; Aardening, P.; Ridder, D.D.; Vet, E.D. Eating behaviour and food purchases during the COVID-19 lockdown: A cross-sectional study among adults in the Netherlands. Appetite 2020, 157, 105002. [CrossRef]

11. Kostev, K.; Lauterbach, S. Panic buying or good adherence? Increased pharmacy purchases of drugs from wholesalers in the last week prior to COVID-19 lockdown. J. Psychiatr. Res. 2020, 130, 19-21. [CrossRef] [PubMed]

12. Laato, S.; Najmul Islam, A.K.L.; Farooq, A.; Dhir, A. Unusual purchasing behaviour during the early stages of the COVID-19 pandemic: The stimulus-organism-response approach. J. Retail. Consum. Serv. 2020, 57, 102224. [CrossRef]

13. Mehta, S.; Saxena, T.; Purohit, N. The New Consumer Behaviour Paradigm amid COVID-19: Permanent or Transient? J. Health Manag. 2020, 22, 291-301. [CrossRef]

14. United Nations [UN]. In Focus: Gender Equality Matters in COVID-19 Response. 2020. Available online: https:/ /www.unwomen. org/en/news/in-focus/in-focus-gender-equality-in-covid-19-response?gclid=Cj0KCQjw28T8BRDbARIsAEOMBcwrrNvUaMSs1 d7L9Wd-Y-MXujrSDVSFajfZv6NxowMn9mGxIG5pcScaAgmzEALw_wcB (accessed on 22 October 2020).

15. Gouda, H. The impact of the sense of security in young employees on job satisfaction during COVID-19 pandemic. Int. J. Adv. Appl. Sci. 2020, 7, 51-57. [CrossRef]

16. Carranza, E.; Farole, T.; Gentilini, U.; Morgandi, M.; Packard, T.; Santos, I.; Weber, M. Managing the Employment Impacts of the COVID-19 Pandemic: Policy Options for Relief and Restructuring. Jobs Working Paper No. 49. 2020. Available online: http:/ /hdl.handle.net/10986/34263 (accessed on 6 October 2020).

17. Demir, S.S.; Nas, O.E.; Acar, E.A. Jobs at Risk in Turkey: Identifying the Impact of COVID-19. Social Protection and Jobs Discussion Paper No. 2004. 2020. Available online: http:/ / hdl.handle.net/10986/34360 (accessed on 18 November 2020).

18. La Torre, G.; Di Thiene, D.; Cadeddu, C.; Ricciardi, W.; Boccia, A. Behaviours regarding preventive measures against pandemic H1N1 influenza among Italian healthcare workers. Eurosurveillance 2009, 14, 19432. [CrossRef] [PubMed]

19. Hussien, H. Descriptive epidemiological analysis of the coronavirus disease 2019 (COVID-19) pandemic. Int. J. Adv. Appl. Sci. 2020, 7, 105-112. [CrossRef]

20. Tröster, B.; Küblböck, K. Unprecedented but not Unpredictable: Effects of the COVID-19 Pandemic on Commodity-Dependent Countries. Eur. J. Dev. Res. 2020, 32, 1430-1449. [CrossRef] [PubMed] 
21. Al-shahrani, S.M.; Alshahrani, N.Z.; Mohammed, S.D.; Mohammed, H.M.; Fahad, Y.; Hamed, A.N. Perspective of healthcare workers regarding self-protection during COVID-19 pandemic: A cross-sectional study from Saudi Arabia. Int. J. Adv. Appl. Sci. 2020, 8, 101-105.

22. Halvatsiotis, P.; Kotanidou, A.; Tzannis, K.; Jahaj, E.; Magira, E.; Theodorakopoulou, M.; Konstandopoulou, G.; Gkeka, E.; Pourzitaki, C.; Kapravelos, N.; et al. Demographic and clinical features of critically ill patients with COVID-19 in Greece: The burden of diabetes and obesity. Diabetes Res. Clin. Pract. 2020, 166, 108331. [CrossRef]

23. Lee, M.C. Factors influencing the adoption of internet banking: An integration of TAM and TPB with perceived risk and perceived benefit. Electron. Commer. Res. Appl. 2009, 18, 130-141. [CrossRef]

24. Mitchell, V. Consumer perceived risk: Conceptualisations and models. Eur. J. Mark. 1999, 33, 163-195. [CrossRef]

25. Mitchell, V.W.; Harris, G. The importance of consumers' perceived risk in retail strategy. Eur. J. Mark. 2005, 90, 821-837. [CrossRef]

26. Baker, S.R.; Farrokhnia, R.A.; Meyer, S.; Pagel, M.; Yannelis, C. How Does Household Spending Respond to an Epidemic? Consumption during the 2020 COVID-19 Pandemic, NBER Working Paper 26949. 2020. Available online: https://www.nber.org/ papers/w26949 (accessed on 1 June 2020).

27. Carvalho, B.; Peralta, S.; Santos, J.P.D. What and How Did People Buy during the Great Lockdown? Evidence from Electronic Payments. CARES Working Paper. 2020. Available online: https://ideas.repec.org/p/eca/wpaper/2013-307531.html (accessed on 15 June 2020).

28. Dou, Z.; Stefanovski, D.; Galligan, D.; Lindem, M.; Rozin, P.; Chen, T.; Chao, A.M. The COVID-19 Pandemic Impacting Household Food Dynamics: A Cross-National Comparison of China and the U.S. SocArXiv Papers. 2020. Available online: https: / / doi.org/10.31235/osf.io/64jwy (accessed on 14 June 2020).

29. Ker, A.P.; Cardwell, R. Introduction to the special issue on COVID-19 and the Canadian agriculture and food sectors: Thoughts from the pandemic onset. In: COVID-19 and the Canadian Agriculture and Food Sectors: Thoughts from the Pandemic Onset. Can. J. Agric. Econ. Rev. Can. D'agroeconomie 2020, 68, 139-142. [CrossRef]

30. Lu, H.P.; Hsu, C.L.; Hsu, H.Y. An empirical study of the effect of perceived risk upon intention to use online applications. Inf. Manag. Comput. Secur. 2020, 13, 106-120. [CrossRef]

31. Meyer, S. Understanding the COVID-19 Effect on Online Shopping Behaviour. Big Commer. 2020, 2, 1-16.

32. Savarese, M.; Castellini, G.; Morelli, L.; Graffigna, G. COVID-19 disease and nutritional choices: How will the pandemic reconfigure our food psychology and habits? A case study of the Italian population. Nutr. Metab. Cardiovasc. Dis. 2020, 31, 399-402. [CrossRef] [PubMed]

33. Tucker, C.E.; Yu, S. The Early Effects of Coronavirus-Related Social Distancing Restrictions on Brands. Available online: https:/ / ssrn.com/abstract=3566612 (accessed on 1 October 2020).

34. Dai, B.; Forsythe, S.; Kwon, W.S. The impact of online shopping experience on risk perceptions and online purchase intentions: Does product category matter? J. Electron. Commer. Res. 2013, 15, 13-24.

35. Hamidizadeh, A.; Taghavi, H.; Rahi, S.M. Studying consumer behaviour antecedents among mobile phone advertisements users. Int. J. Adv. Appl. Sci. 2016, 3, 41-48.

36. Chaudary, M.W.T.; Furqan, A.; Gill, M.S.; Rizwan, M. The determinants of purchase intention of consumers towards counterfeit shoes in Pakistan. J. Public Adm. Gov. 2014, 4, 20-38. [CrossRef]

37. Krakowiak, M.K. Women are more likely to buy unknown brands than men: The effects of gender and known versus unknown brands on purchase intentions. J. Retail. Consum. Serv. 2021, 58, 102273. [CrossRef]

38. Yi, Y. Cognitive an Affective Priming of the Context for Print Advertisements. J. Advert. 1990, 19, 40-48. [CrossRef]

39. Mahmoud, T.O. Impact of green marketing mix on purchase intention. Int. J. Adv. Appl. Sci. 2017, 5, 127-135. [CrossRef]

40. Centers for Disease Control and Prevention [CDC]. Coronavirus Disease 2019 (COVID-19): Manage Anxiety \& Stress. 2020. Available online: https:/ / www.cdc.gov/coronavirus/2019-ncov/prepare/managingstress-anxiety.html (accessed on 16 March 2020).

41. Conchar, M.; Zinkhan, G.; Peters, C.; Olavarrieta, S. An integrated framework for the conceptualization of consumers' perceivedrisk processing. J. Acad. Mark. Sci. 2004, 32, 418-436. [CrossRef]

42. Zikmund, W.; Scott, J. A multivariate analysis of perceived risk and self-confidence and information sources. Adv. Consum. Res. 1974, 1, 406-416.

43. Gilmore, J.; Pine, B. Differentiating Hospitality Operations via Experiences. Cornell Hotel Restaur. Adm. Q. 2002, 43, 87-96. [CrossRef]

44. Kim, Y.K.; Sullivan, P. Emotional branding speaks to consumers' heart: The case of fashion brands. Fash. Text. 2019, 6, 1-16. [CrossRef]

45. Belk, R.W.; Güliz, G.; Søren, A. The Fire of Desire: A Multisited Inquiry into Consumer Passion; University of Utah Marketing Working Paper No. 02-31; The University of Utah: Salt Lake City, UT, USA, 2002; Available online: http: / dx.doi.org/10.2139/ssrn.354640 (accessed on 16 March 2020).

46. Meyer, C.; Schwager, A. Understanding customer experience. Harv. Bus. Rev. 2007, 85, 117-126.

47. Allport, G.W. Attitudes. In Handbook of Social Psychology, 1st ed.; Murchison, C., Ed.; Clark University Press: Worcester, UK, 1935.

48. Engel, J.F.; Kollat, D.T. Comsumer Behaviour, The Role of The Consumers in Marketing; HRS Inc.: New York, NY, USA, 1982.

49. Belk, R.W. Possessions and the Extended Self. J. Consum. Res. 1988, 15, 139-168. [CrossRef]

50. Belk, R.W.; Sherry, J.; Wallendorf, M. The Sacred and the Profane in Consumer Behavior: Theodicy on the Odyssey. J. Consum. Res. 1989, 16, 1-38. [CrossRef] 
51. Baron, R.M.; Kenny, D.A. The moderator-mediator variable distinction in social psychological research: Conceptual, strategic, and statistical considera-tions. J. Personal. Soc. Psychol. 1986, 51, 1173-1182. [CrossRef]

52. Cunningham, S.M. Perceived risk and brand loyalty. In Risk Taking and Information Handling in Consumer Behaviour, 1st ed.; Cox, D.F., Ed.; Boston University Press: Boston, MA, USA, 1967; pp. 507-523.

53. Roselius, T. Consumer rankings of risk reduction methods. J. Mark. 1971, 35, 56-61. [CrossRef]

54. Kaplan, L.; Szybillo, G.; Jacoby, J. Components of perceived risk in product purchase: A cross-validation. J. Appl. Psychol. 1974, 59, 287-291. [CrossRef]

55. Schiffman, L.G.; Kanuk, L.L. Consumer Behaviour, 8th ed.; Prentice Hall: Upper Saddle River, NJ, USA, 2004.

56. Ministry of Health [MH]. Dietary Guidelines for Saudis. The Healthy Food Palm. Report of the General Directorate of Nutrition. 2012. Available online: https://www.moh.gov.sa/en/Ministry/MediaCenter/Publications/Documents/final\%20english\%20 \%20\%D8\%A7\%D9\%84\%D9\%83\%D8\%AA\%D8\%A7\%D8\%A8\%20\%D8\%A7\%D9\%84\%D8\%B9\%D9\%84\%D9\%85\%D9\%8A\%20 \%D8\%A5\%D9\%86\%D8\%AC\%D9\%84\%D9\%8A\%D8\%B2\%D9\%8A.pdf (accessed on 25 December 2019).

57. Ramadan, M.F.; Elsanhoty, R.M.; Al-Turki, A.I. Chapter 41: Usage of Genetically Modified Foods: The Extent of Genetically Modified Rice, Maize, and Soy Consumption in Saudi Arabia. In Genetically Modified Organisms in Food Production, Safety, Regulation and Public Health, 1st ed.; Watson, R.R., Preedy, V.R., Eds.; Academic Press: Cambridge, MA, USA, 2016 ; pp. 467-479.

58. Alsubaie, A.S.R. Consumption and correlates of sweet foods, carbonated beverages, and energy drinks among primary school children in Saudi Arabia. Saudi. Med. J. 2017, 38, 1045-1050. [CrossRef]

59. Al-Jawaldeh, A.; Taktouk, M.; Nasreddine, L. Food Consumption Patterns and Nutrient Intakes of Children and Adolescents in the Eastern Mediterranean Region: A Call for Policy Action. Nutrients 2020, 12, 3345. [CrossRef] [PubMed]

60. Huffman, C.; Kahn, B. Variety for sale: Mass customization or mass confusion? J. Retail. 1998, 74, 491-513. [CrossRef]

61. Herpen, E.V.; Pieters, R. The Variety of an Assortment: An Extension to the Attribute-Based Approach. Mark. Sci. 2002, 21, 223-367. [CrossRef]

62. Kahn, B.E.; Wansink, B. The Influence of Assortment Structure on Perceived Variety and Consumption Quantities. J. Consum. Res. 2004, 30, 519-533. [CrossRef]

63. Morales, A.; Kahn, B.E.; McAlister, L.; Broniarczyk, S.M. Perceptions of assortment variety: The effects of congruency between consumers' internal and retailers' external organization. J. Retail. 2015, 81, 159-169. [CrossRef]

64. Chernev, A. When More Is Less and Less Is More: The Role of Ideal Point Availability and Assortment in Consumer Choice. J. Consum. Res. 2015, 30, 170-183. [CrossRef]

65. Iyengar, S.S.; Lepper, M.R. When choice is demotivating: Can one desire too much of a good thing? J. Personal. Soc. Psychol. 2000, 79, 995-1006. [CrossRef]

66. Lin, C.Y. Social reaction toward the 2019 novel coronavirus (COVID-19). Soc. Health Behav. 2020, 3, 1-2. [CrossRef]

67. Ahorsu, D.K.; Lin, C.Y.; Imani, V.; Saffari, M.; Griffiths, M.D.; Pakpour, A.H. The Fear of COVID-19 Scale: Development and Initial Validation. Int. J. Ment. Health Addict. 2020, 3, 1. [CrossRef]

68. Centers for Disease Control and Prevention [CDC]. Coronavirus Disease 2019 (COVID-19): Reducing Stigma. 2020. Available online: https: / / www.cdc.gov/coronavirus/2019-ncov/about/related-stigma.html (accessed on 16 March 2020).

69. Guan, W.J.; Ni, Z.Y.; Hu, Y.; Liang, W.H.; Ou, C.Q.; He, J.X.; Du, B. Clinical characteristics of coronavirus disease 2019 in China. N. Engl. J. Med. 2020, 382, 1708-1720. [CrossRef]

70. Huang, C.; Wang, Y.; Li, X.; Ren, L.; Zhao, J.; Hu, Y.; Zhang, L.; Fan, G.; Xu, J.; Gu, X.; et al. Clinical features of patients infected with 2019 novel coronavirus in Wuhan, China. Lancet 2020, 395, 497-506. [CrossRef]

71. Evrard, Y.; Pras, B.; Roux, E. Market. Études et Recherches en Marketing, 3rd ed.; Dunod: Malakoff, France, 2003.

72. Churchill, J.A.; Peter, J.P. Research Design Effects on the Reliability of Rating Scales: A Meta-Analysis. J. Mark. Res. 1984, 21, 360-375. [CrossRef]

73. Joosten, E.M.D.; Vanderelst, B.; Pelemans, W. The effect of different diagnostic criteria on the prevalence of malnutrition in a hospitalized geriatric population. Aging Clin. Exp. Res. 1999, 11, 390-394. [CrossRef] [PubMed]

74. Giannelloni, J.L.; Vernette, E. Etudes de Marché, 5th ed.; Vuibert: Paris, France, 2019.

75. Arnold, M.J.; Reynolds, K.E. Hedonic Shopping Motivations. J. Retail. 2013, 79, 259-268. [CrossRef]

76. Badot, O.; Bernard, C.O.V.A. Néo-marketing, 10 ans après: Pour une théorie critique de la consommation et du marketing réenchantés. Rev. Française Mark. 2003, 195, 79-94.

77. Browne, M.W.; Cudeck, R. Alternative Ways of Assessing Model Fit. Sociol. Methods Res. 1992, 21, 230-258. [CrossRef]

78. Thorndike, R.M. Book Review: Psychometric Theory (3rd ed.) by Jum Nunnally and Ira Bernstein New York: McGraw-Hill, 1994, xxiv+752pp. Appl. Psychol. Meas. 1995, 19, 303-305. [CrossRef]

79. Lumpkin, J.; Dunn, M. Perceived risk as a factor in store choice: An examination of inherent versus handled risk. J. Appl. Bus. Res. 1990, 6, 104-118. [CrossRef]

80. Cases, A.S. Perceived risk and risk-reduction strategies in Internet shopping. Int. Rev. Retail. Consum. Res. 2002, 12, 375-394. [CrossRef]

81. Cases, A.S. Effets des combinaisons de réducteurs sur le risque perçu dans le contexte de l'achat électronique sur Internet. In Proceedings of the Congrès International de l'Association Française de Marketing, Lille, France, 23 May 2002; pp. $273-286$.

82. Laroche, M.; Bergeron, J.; Goutaland, C. How intangibility affects perceived risk: The moderating role of knowledge and involvement. J. Serv. Mark. 2003, 17, 122-140. [CrossRef] 
83. Schmitt, B.H. Experiential marketing. J. Mark. Manag. 1999, 15, 53-67. [CrossRef]

84. Schmitt, B.H. Experiential Marketing: How to Get Customers to Sense Feel Think Act Relate to your Company and Brands, 1st ed.; The Free Press: New York, NY, USA, 1999.

85. Gonzalez, C.; Korchia, M. Attitudes Toward Seasonal Sales: An Exploratory Analysis of the Concept and Its Antecedents. In E-European Advances in Consumer Research, 7th ed.; Ekstrom, K.M., Brembeck, H., Eds.; Association for Consumer Research: Goteborg, Sweden, 2005; pp. 486-491.

86. Aurier, P.; Siadou-Martin, B. Perceived justice and consumption experience evaluations: A qualitative and experimental investigation. Int. J. Serv. Ind. Manag. 2007, 18, 450-471. [CrossRef]

87. Fornell, C.; Larcker, D.F. Structural equation models with unobservable variables and measurement error: Algebra and statistics. J. Mark. Res. 1981, 18, 382-388. [CrossRef]

88. Hosmer, D.W.; Lemeshow, S. Goodness of fit tests for the multiple logistic regression model. Commun. Stat. Theory Methods 1980, 9, 1043-1069. [CrossRef] 